\title{
The limits of participatory democracy and the rise of the informal politics of mediated representation in South Africa
}

\author{
Laurence Piper $^{\mathrm{a}}$ and Bettina von Lieres ${ }^{\mathrm{b}}$ \\ ${ }^{\mathrm{a} D e p a r t m e n t}$ of Political Studies, University of the Western Cape, Cape Town, South Africa; ${ }^{\mathrm{b}}$ Centre for Critical \\ Development Studies, University of Toronto Scarborough, Toronto, Canada
}

\begin{abstract}
In general, South Africans view the formal participatory institutions of their state as ineffective mechanisms for the realization of their demands. Conversely, the reach of formalized civil society is limited in terms of policy impact, and social movements have little presence on the ground outside of the larger townships of the major metropolitan cities. In this context, the tensions between communities, civil society actors, and the state, often linked to enduring forms of poor governance, are increasingly played out in non-state and extra-institutional arenas, sometimes through the idiom of protest. Marginalized communities rely on various kinds of informal political practices to access rights and services from the state, or even to keep the state at bay. This emerging informal politics, and the associated forms of mediated representation, speaks to an ever-widening legitimacy gap between state and society, and with it, an ever-precarious participatory project.
\end{abstract}

\section{KEYWORDS}

State-society relations; South Africa; participatory governance; invited and invented spaces; informal politics; insurgency; quiet acquiescence; clientelism

\section{Introduction}

South Africa's first democratic elections in 1994 ushered in what many refer to as a 'transition to democracy' (Jeeves, 2004, p. 508) which involved the dismantling of the apartheid state apparatus and the dissemination of public discourses promising participatory governance. From the beginning, the 'participatory turn' in South Africa carried deep emancipatory ideals and objectives: The reversal of deep social exclusion, the radical transformation of state/society relations and the establishment of a new democratic politics of representation and participation. In contrast to many Northern contexts, the 'participatory turn' in South Africa did not simply involve the expansion and democratizing of already-existing participatory and representative institutions. It was predicated, first and foremost, on the successful dismantling of authoritarian state institutions and the establishment of a liberal democratic order, including a substantial rights framework. The South African Constitution played a crucial role in creating a rights framework for civil society activism and mobilization, especially in the area of health activism.

Second, from 1994 onwards, both state and civil society championed participation as a means to reconfigure state power. A range of actors across the state/civil society divide, 
actors who had previously learnt their political practices in anti-apartheid social movements, supported the idea of 'people's power' and 'grassroots participation' as core principles for a new democratic state.

Immediately after the first elections, however, it quickly became clear that many of the new state officials were reluctant to clarify concrete policy and institutional proposals for participatory democracy beyond the mainstream liberal model. With constitutional negotiations dominated by party elites and their teams of lawyers, popular conceptions of participatory governance were limited to aspects of local government and governance, largely as an institutional design afterthought (Barichievy, Piper, \& Parker, 2005). Correspondingly, the participatory practices exemplified by anti-apartheid civil society in the 1980s dissolved from mainstream politics with the dismantling of civil society structures like the United Democratic Front (UDF) in the re-building of the ruling political party, the African National Congress (ANC) after 1990. Organizationally, this proved a hammer-blow from which civil society has yet to recover fully, and indeed is constrained in doing so by the logic of party capture that positions the ANC and its allies, rather than independent civil society, as the representatives of the people.

Furthermore, despite a clearer focus on emancipatory goals, the remaining and new civil society actors failed to generate clearer pragmatic discourses on participation. In fact, for civil society movements, participation became, above all, an umbrella term for an expanding range of normative goals: Justice, freedom, citizenship, rights recognition, equality, inclusion and empowerment-all of which were never dissected into more detailed institutional proposals (Friedman \& Mottiar, 2005; von Holdt et al., 2011; von Lieres \& Robins, 2008; Meth, 2010; Miraftab \& Wills, 2005).

The initial lack of clarity on the institutional dimensions of participatory democracy, coupled with the state's tendency to be party-dominated and to distrust unaffiliated citizen groups, has continued to define and weaken South Africa's post-apartheid democracy-building project. Indeed, party dominance has enabled rent-seeking coalitions of political and business networks, particularly at provincial and local levels to capture state development projects for their own ends and at the expense of the poor residents. Exemplified in the relationship between President Zuma and the wealthy Gupta family, this is a practice on the rise across the country. Indeed, many of the conflicts in government and between government and communities are linked to competing clientelistic networks within the ruling party, or even between the ruling party and some opposition parties. Not all protests are citizens holding the state accountable in democratic terms; some are clients mobilized to support their patrons against their rivals within the same political party.

Because of the failure of participatory governance, the limited reach of civil society, and the larger context of growing clientelistic politics, informal forms of representation increasingly dominate state-society relations. In addition to the formal processes of public consultation and the rights-based citizenship championed by social movements, there are many further and informal forms of popular politics. Each of these includes various forms of mediation. The main ones include forms of quiet encroachment where those who cannot live within the law, like migrants and many of the urban poor, look to avoid the state if possible, and popular insurgency where the differential logics of the emerging post-apartheid social order are explicitly contested from below. Much, but 
not all, of the protest that has characterized popular politics for the last decade is evidence of this swelling dissatisfaction.

Notably, in much of this alternative politics, located outside of formal state and civil society institutions, third-party actors have emerged to play a crucial mediating and representative role for citizens in their relations with the state. This includes a range of actors from formal civil society organizations to community-based organizations and informal networks of local leaders who play a role engaging the state for various ends, whether democratic, clientelistic or other. We suggest that, in the context of party capture, this ambiguous politics of mediation has replaced participation in formal institutions as the key way in which state and society engage in South Africa.

In making this case, the article begins by outlining the failure of formal participatory governance in South Africa due to poor institutional design and de facto capture into other informal political logics. It then moves to explain the limited impact of formal civil society on much of the state due to the prioritization of political society over civil society during the transition, and the partisan capture of community representation in much of the country. Lastly, drawing on an emergent literature on the significance of mediation in state-society relations across the global South, the article points to the growing significance of the informal politics of representation in South Africa. Key here are the ways in which citizens are increasingly represented to the state, and the state to the citizens, by unelected intermediaries including non-governmental organizations (NGOs), political parties, social movements, community civic leaders, and networks of individuals.

We organize the argument into three sections: The invited and invented spaces of formal participation as constructed by the liberal democratic legal order, and lastly the emergent informal forms of mediated representation.

\section{Invited spaces: post-apartheid participatory institutions}

The post-apartheid political order was ushered in with the first non-racial elections of 1994, shortly followed by the Constitution of 1996. Negotiations created a unitary state with most of the institutions typical of a liberal democracy including constitutional sovereignty, a bill of rights, regular free and fair elections, and a weak form of federalism. In addition, the constitution provided for an independent judiciary, a number of formal checks and balances on executive power and the institutionalization of participatory democracy. References to participation in post-apartheid local government can be found in Section 195 (e) of the South African Constitution of 1996 that states that in terms of the basic values and principles governing public administration-people's needs must be responded to, and the public must be encouraged to participate in policy-making'.

Since the first democratic elections in 1994, discourses of 'participatory democracy' and 'participatory governance' circulated widely and publicly amongst state officials, civil society actors, scholars, and activists. The policy framers of early participation legislation had all been civic anti-apartheid activists in community organizations who had disseminated deep public critiques of the racialized apartheid system of representation (Piper \& von Lieres, 2008). Primary amongst these was that liberal and representative democracy is an insufficient political system to overcome deep-seated economic and social exclusion of 
the majority of people. While recognizing the importance of representative democracy, especially since under the apartheid state the majority of people had no franchise, state officials and civil society actors early on argued for the need to complement representative democracy with participatory structures in order to address exclusion.

Emergent from the discourse were a number of different participatory structures, almost entirely at the local level, including requirements for community representation on school governing bodies, community policing forums, hospital boards, catchment management authorities, and various requirements for community participation on development projects (Friedman, 2006). Arguably, the most developed of all these, however, is the system of 'participatory governance' that is a legal requirement of local government. Hence, in what follows, we focus on this domain as the exemplar of larger logics of formal participatory governance in South Africa. While there are also requirements for forms of consultation in provincial and national policymaking and law-making, these are forms of engagement consistent with conventional liberal democracy rather than the direct participation imagined in popular resistance politics of the 1980s.

The first noteworthy fact is that participatory governance institutions are located in local government rather than in the provincial or national spheres. This reflects the relative neglect of this concept institutionally by the party elites who negotiated the transition to electoral democracy in South Africa. Indeed, in general, local government was regarded as less important than the other spheres. Thus, according to former President Thabo Mbeki, speaking at the Local Government Bargaining Council Sector Summit on 1 March 2005, 'the primary focus has been on national government as "absolutely important", provincial government as "important" and local government as "well, it exists" (The Witness 3 March 2005).

Consequently, it was only as late as 2000 , some six years after national and provincial institutions were established, that the final form of local government design was decided upon with the Local Government: Municipal Systems Act of 2000. This act included the requirement 'to develop a culture of municipal governance that complements formal representative government with a system of participatory governance'. As argued by Barichievy et al. (2005), participatory governance amounted to three things: (i) The definition of residents as one of three components parts of the municipality, (ii) the establishment of ward committees of around ten members to assist the ward councillor in engaging the local community in the ward (the smallest spatial unit in the democratic political system), and (iii) requirements for public consultation around key decision-making processes including the annual budget and development planning.

International literature on effective and democratic forms of participatory governance suggests that institutional design matters, with Fung and Wright (2001) arguing that successful institutions have: (i) A practical orientation to specific issues that concern citizens; (ii) forms of bottom-up participation where those directly affected must participate in the deliberation on solutions; and (iii) deliberative solution generation such that decisions must be made according to principles of equal access, voice, and impact on outcomes. In addition to these principles, they also note that participatory institutions must have the power to take real decisions to be effective; and that this power requires state support to be effective and sustainable over time. This model Fung and Wright term 'empowered participatory governance'. 
In addition to questions of institutional design, several authors note that political support from politicians is important, especially to get new institutions up and running (Baiocchi, Heller, \& Silva, 2011; Gaventa, McGee, \& Zipfel, 2007). In addition to political will 'from above', also important is the popular mobilization of citizens 'from below' into these new spaces, especially popular mobilization of historically marginalized groups. Critical here is civil society, but also the history of state-society relations for creating the larger context conducive to institutional innovations (Cornwall \& Coelho, 2007; Mohanty, Thompson, \& Coelho, 2011). In sum then, effective participatory governance requires what Gaventa et al. (2007) terms 'working both sides of the equation' of statesociety relations, reflecting a high level of co-operation between state and society actors, as well as well-designed institutions.

Research into the implementation of 'participatory governance' in the sphere of local government in South Africa over the last ten years reveals an ineffective and not especially democratic system. To a significant extent, this much is implied with the dramatic growth in popular protest over the same period (Alexander, 2010; von Holdt et al., 2011), but is also confirmed by almost all more directed research on ward committees and public engagement around core municipal processes. Hence, in terms of ward committees, not only are ward councillors among the most disempowered members of a local municipality (Bénit-Gbaffou, 2008), but ward committees are designed not as participatory structures but as representative ones that tend to be dominated by the ward councillor and local party branch (Piper \& Deacon, 2009). Furthermore, they are deliberately designed as advisory structures to the ward councillor and typically have no decision-making powers. Indeed, their very functionality is an extension of the ward councillor's will (Piper \& Deacon, 2009).

These narratives of disempowered and marginalized participation are echoed in the research in public consultation around municipal budget and integrated development plan (IDP) processes. As noted by several researchers, the approach is typically one of minimal compliance involving the presentation of draft budget and IDPs to public meetings, with a few minutes for oral or written questions (Buccus, Hemson, Hicks, \& Piper, 2008; Friedman, 2006; Piper \& Nadvi, 2010). Perhaps this approach is not surprising, for, as noted in Section 16(2) of the Local Government: Municipal Systems Act of 2010, the requirement to establish a system of participatory governance 'must not be interpreted as permitting interference with a municipal council's right to govern and to exercise the executive and legislative authority of the municipality'. Ultimately then, the law located the ultimate right to rule with elected representatives and not the public, and as Barichievy et al. (2005) observe, allows municipalities to cherry pick which participatory decisions they want to implement. Lastly, it is worth recalling that many of the issues central to people's well-being such as security, health, education, housing, and employment are overwhelmingly the responsibility of national and provincial government, and thus not the purview of local government and its system of 'participatory governance'. Hence, direct popular participation in decision-making over the key issues that affect people's lives is thus, by design, not possible.

Despite this, however, research reveals that the formal institutions of participatory governance show signs of significant political life (Bénit-Gbaffou, 2015). A key reason for this is that these spaces become terrains in which other kinds of politics, often more personal or clientelistic, are pursued (Bénit-Gbaffou, 2015). Key to understanding this is 
recognizing that government's weak attempt to institutionalize participatory governance went hand in glove with the ruling party's own centralized understanding of statesociety relations. From 1994 onwards, the practice of politics was rendered centrifugal through the electoral dominance of the former liberation movement, the ANC. In addition, prominent leaders in the ANC saw little difference between state and society (and hence between state and citizens) as in their view the new democratic state was inherently the legitimate representative of the people. The belief that the state always and necessarily acted in the interests of citizens ('state-as-citizen') was as widely defended by ANC leaders as it was criticized by civil society leaders (often not aligned to the ANC) who asserted the importance of distinguishing between state, civil society, and citizens (Heller, 2001, 2009; von Lieres \& Robins, 2008; Piper, 2015).

The failure to institutionalize citizen participation can be traced back to the ANC's own assumptions about its representative authority and legitimacy. These assumptions are reflected in the idea that the ANC is both a political party and a social movement (Booysen, 2011), and that, in the language of liberation nationalism, the party is the sole legitimate representative of the oppressed black majority in South Africa, a fact seemingly confirmed by its overwhelming victories at every national election since 1994 (Piper, 2015). For these institutional, ideological, and electoral reasons, the ANC has tended to elide nation with movement and party, and more recently, party with the state, underestimating the crucial importance of independent citizen institutions. The government simply assumed that the new political institutions naturally would be democratic institutions without taking into account that democracy is dependent on institutionalizing the right to participate in decision-making between elections. However, many of the contemporary issues of poor governance can be traced to the emerging practice of the 'partystate' that are undermining governance and creating a legitimacy crisis for the party that shows little sign of abating into the future (Piper, 2015; Piper \& Anciano, 2015).

\section{Invented spaces: social movements and rights-based citizenship}

The failure of formal spaces of participatory governance is important, but only part of the story of participation in South African politics. Following Cornwall's (2002, p. 17) framing of formal institutions as 'invited spaces' of participation created 'from above' by the state in contrast to the 'organic' or 'invented spaces' created by citizens, we also need to consider the initiatives 'from below' in state-society relations in South Africa. Examples of this include Miraftab's (2006) description of rights-based forms of citizenship where the urban poor challenges the invited spaces of state rule. Key to understanding the possibility of this kind of politics is the establishment, in terms of the Bill of Rights in the 1996 Constitution, a regime of rights that includes key political and civil rights such as the freedom of opinion, freedom from arbitrary arrest, and the rights to association, protest, and state information.

Perhaps the most high-profile instances of rights-based citizenship advanced 'from below' in post-apartheid South Africa are the new social movements of the late 1990s. These movements included the Treatment Action Campaign (TAC), the Concerned Citizen's Forum, the Anti-Privatization Forum, the Soweto Electricity Crisis Committee, the Landless People's Movement, the Western Cape Anti-Eviction Campaign, Abahlali 
baseMjondolo ('the people who live in shacks'/'shack dwellers'), the Equal Education Campaign and the Social Justice Coalition (Ballard, Habib, \& Valodia, 2006; Zuern, 2011).

Path breaking amongst these social movements was the TAC. Established on 10 December 1998 when a group of about 15 people protested on the steps of Saint George's Cathedral in Cape Town to demand medical treatment for people living with HIV, the TAC developed into one of South Africa's most effective post-apartheid social movements. It mobilized citizens in multiple arenas-the courts, the streets, the media and global forums - and succeeding in winning important reforms in national policy on access to treatment, and with it, greater state responsiveness to citizens' demands (Robins \& von Lieres, 2008). The coalition built by the TAC involved complex and highly developed mobilizing structures that linked national reformers to local and faithbased groups, the media and repositories of medical expertise (Piper, Bafo, \& von Lieres, 2012). In bringing together practices of grassroots resistance and political collaborations with powerful interest groups around a 'slow activism' of sustained social transformation (Robins, 2014), the TAC acted as an important mediator between professionals with access to medical knowledge and state/political networks, and the vast majority of the organization's working and poor membership.

The failure of formal participatory institutions during 1999-2004 and the concurrent rise of the TAC and its ilk significantly shaped the politics of participation in post-apartheid South Africa for a number of reasons: First, they both indicated the growing lack of vertical institutionalized democratic relations between citizens and the ANC-led state. The post-apartheid social contract brokered by elites during negotiations was never properly authorized by citizens through the system of participatory governance after 1994 . Indeed, if anything, the practical exclusion of independent citizen voice and control from participatory governance mirrored their exclusion from the formative elite bargain. Secondly, the rise of the TAC firmly situated struggles for democratic citizenship and rights in civil society, outside of state power and formal political institutions, and in the realm of 'third-party' representation and mediation (von Lieres \& Piper, 2014).

The TAC's layered representational role exercised 'advocacy' by championing the rights and needs of ordinary citizens to the state. It also exercised 'empowerment' mediation by teaching global health science and building state-orientated forms of health citizenship amongst their membership living with HIV (von Lieres \& Piper, 2014, p. 110). Many of the outcomes of the TAC's work were democratic in the sense that they led to rightsbased gains for marginalized communities and to greater capacities for self-representation and claim making. The TAC prominently highlighted the importance of informal mediators and participation to the democratizing of state-society relations in South Africa by building citizens' capacities to engage the state.

Similarly, the Equal Education (EE) movement, a social movement focused on improving public education in South Africa and mobilizing youth, emerged in the last decade as a 'second-generation' civil society movement following the successes of the TAC. Robins and Fleisch (2014) have shown how the EE quickly developed into an active grassroots movement, mediating and building a 'pedagogy of active citizenship' in the largest working-class township in Cape Town, Khayelitsha. The EE's first campaign, the 'Broken Windows Campaign', focused on repairing broken windows at a local school in Khayelitsha, and included engaging the provincial government, meeting with school management and circulating petitions. It resulted in the provincial government fixing the 
windows. The EE quickly expanded into other townships in Cape Town and expanded its activities in other parts of the country. In December 2012, the EE succeeded in pressuring the Minister of Basic Education to enact national Minimum Norms and Standards for School Infrastructure (Robins and Fleisch, 2014). It also developed powerful networks with other civil society organizations and labour unions.

Throughout these campaigns, the EE placed emphasis on building the long-term capacity of working-class youth, thus brokering a pedagogy of active citizenship in working-class communities. Like the TAC, it used a variety of tactics from the court to protests to alliances with trade unions. It initiated campaigns ranging from local demands to repair broken classroom windows to wider engagements to change national regulations. The movement also developed a critical pedagogy concerned with establishing the rights of citizens to mobilize for decent public schooling, in particular secondary school learners in under-resourced schools in Khayelitsha in Cape Town. Robins and Fleisch (2014, p. 143) argue that access to social capital, upward social mobility and organizational skills can 'facilitate activists' access to institutional spaces that they ordinarily would not be able to enter'. The learners and the leaders of the EE act as mediators of a new 'critical pedagogy of active citizenship' at the heart of this rights-based social movement (Robins and Fleisch, 2014).

In both these cases, the mediators are social movements engaged in playing informal as well as formal representative and mediating roles. Both of these social movements engaged wider networks that included diverse actors aside from the state and citizens. Both the TAC and the EE used wider networks of political actors instead of formal representative or participatory institutions to construct and re-construct state-society relations in the process of contesting state policies and demanding greater state responsiveness. Informal networks and alliances (situated between state and society) were crucial in securing TAC and $\mathrm{EE}$ access to state services, resources and policy-making. In addition, they played a role in empowering TAC and EE members to build their own capacities as claimmakers and representatives. Both social movements acted as 'advocacy' and 'empowerment' mediators, using negotiation and bargaining, civic mobilization and capacity building rather than confrontation and violence in their forms of informal participation.

As important as the TAC, EE, and other social movements are in South Africa, it is important not to overstate their scale and influence. Hence, while alongside other formal NGOs in professionalized civil society they do have an impact on national policy- and law-making processes, both their impact and organizational reach remain limited. Thus, most social movements have little organized presence outside of the major townships in the metropolitan areas of South Africa, and the majority of poor and marginalized citizens are unlikely to have encountered them directly in any form. Furthermore, the impact from below of organized civil society on the South African polity is typically small, and major deviations in law and policy caused by civil society interventions are the real exception rather than the rule. Political society remains ascendant over civil.

Key to understanding this reality is the relative decline of civil society in South Africa since the 1990s. During the 1980s, civil society was strong. Popular mobilization was channelled into explicitly anti-apartheid activities by urban grassroots organizations mostly united under the umbrella of the UDF that identified with the banned and exiled ANC. Closely associated with the Congress of South African Trade Unions (COSATU), the two organizations captured most popular mobilization behind the political project of 
national liberation. While tremendously effective and important in hastening the end of apartheid, this mobilization of civil society was ended by the democratization process of the 1990s (Ballard et al., 2006, pp. 14-17). Key here was the disbanding of the UDF following the lifting of the ban on the ANC in 1990, and the absorption of civil society leadership into the reconstituted party. Furthermore, after the 1994 elections, most people inside and outside government held the view that government would deliver to the poor (Heller, 2001, p. 134). At the same time, the remaining NGO sector came under pressure to 'professionalize' and withdraw from advocacy to a more limited role in service delivery (Greenstein, 2003). Notably, this demobilization paralleled shifts in donor funding as more foreign aid was channelled into the new democratic state and away from civil society. Thus, while the emergence of the TAC, EE, and other social movements is important in the South Africa participatory landscape, these are exceptional organizations in a context where civil society more generally remains weak.

\section{Informal politics and mediated representation: insurgency, quiet encroachment, and clientelism}

The ineffectiveness of formal institutions of participatory governance, and the limited reach of formal civil society, leaves significant space for a variety of others forms of popular politics. Some of the most important ones are insurgent citizenship, arguably manifest in rising levels of popular protest (although as we shall argue, protest is also linked to clientelism), and quiet encroachment, where residents attempt to avoid altogether the gaze of the state. Finally, yet importantly, are forms of clientelism linked to residents of poor settlements accessing the resources of the state under a dominant party system. Each of these forms of popular politics includes a variety of mediatory representational practices that speak to a widening gap between states and citizens in South Africa.

Coined by Holston (2008), the term insurgent citizenship refers to forms of popular politics that resist state constructions of political subjectivity, asserting democratic alternatives in their place. The popular protests that have grown in number and intensity in South Africa over the last ten years are referred to frequently as evidence of this. Thus, Alexander (2010) describes the protests as evidence of a 'revolt of the poor', and von Holdt et al. (2011) explains them as subaltern resistance intended to 'disrupt the differentiation' of formally equal citizens into new classes (pp. 5-6). Pithouse (2014) too identifies forms of insurgent politics in informal settlements that often escape conventional conceptions of politics. In the context of a largely unresponsive state, participation practices may often be about claiming for 'the right to have rights' and the right to participate in new and multiple public spaces rather than being about democratizing public deliberations, creating mini-publics, or participating in decision-making (Dagnino, 2003).

A focus on informal life in the South African context invariably involves the migrant, more recently the 'foreigner', as target of popular 'xenophobic' violence. Often in South Africa without formal documentation, many refugees from the rest of Africa will deliberately avoid the gaze of the state and look to settle, work and live in urban spaces where state rule is the weakest. Only when threatened collectively with oppression or expulsion does this community organize politically to defend itself, a set of practices that Bayat (1997, 2000) terms 'quiet encroachment', and which he characterizes as common to 
popular politics in repressive political systems in the global South. Although foreign migrants are the archetypal quiet encroachers, this practice can be embraced by any group that cannot live in the city legally, especially those who invade land as they are often too poor to buy and rent legally.

While all of this is evident in popular politics in South Africa outside of formal political and civil society, a less frequently observed form, yet arguably, one of the most widespread and common is clientelism connected to party capture of both state and community in South Africa. As suggested above, key to understanding this is the role of the political party, the ANC. Thus, from 1994, the ANC-led government has continued to assume a close and representative relation with civil society, underestimating the importance of building independent citizen institutions. The ANC remains in a 'tripartite alliance' with the South African Communist Party, and more importantly, COSATU, which is the largest civil society formation in South Africa reinforcing a national hegemony that continues to make oppositional agitation extremely difficult. The ANC is also in alliance with the South African National Civic Organisation, a less organized formation, but representing a patchwork of ANC-aligned leaders at community or residential level.

This alliance, and its local branches, enables the ANC to ground itself as leaders of most poor, black settlements across the country, thus further entrenching the dominance of the ruling party over civil society at the most local level (Piper, 2015). Key here are both the ideology of liberation nationalism that privileges the ANC and its allies as the champion of the oppressed black majority, as well as the privileged access granted by the ANC state to its allies in community and civil society formations (Bénit-Gbaffou, 2012; Piper, 2015; Piper \& Anciano, 2015).

The unparalleled organizational reach of the ANC and its allies enables the extension of the clientelistic logic of the party-state to party-society across the country. This fact, plus the demand by the state (and its partnering) for community leaders to legitimate the projects of the developmental state, means that it is common to find networks of ANC-aligned local leaders positioning themselves between the state and various development projects in most poor, black residential areas. Indeed, in this respect, it is critical to note that the for most poor, black South Africans, the role of the state has shifted significantly since 1994 from being an entity mostly oppressive to being one on which many people rely for their well-being and livelihoods. Thus, not only is South Africa now formally a developmental state primarily responsible for the security, health, education and basic infrastructure (roads, water, electricity, sanitation) of the people, but the government had 16.9 million people (or $30 \%$ of the population) on social grants in September 2015, up from 4 million people (10\%) in 1994 (Africacheck, 2016). This shift of emphasis in the role of the state from coercion to well-being points to the growing importance for the poor majority of accessing the state for key resources.

Notably, the participation of community leaders in clientelistic politics, and, in some cases, even the demand for it from below, reinforces the practice of rent seeking off the state at higher levels by coalitions of politicians and business people. At the national level, this rent seeking is exemplified by President Zuma and the Gupta family, but reflects practices common in many provincial and local governments (Ndletyana, 2015). Notably, much conflict for office centres on competition between rival rent-seeking coalitions within the ruling party, or between rent-seekers and what Du Preez (2016) terms 'contributors', leading to instances of popular mobilization by community leaders interested in 
keeping their patrons in office. The most recent example of this was the large-scale protests in Tshwane over the attempt by the ANC to replace a notorious rent-seeking local politician with a former cabinet minister Thoko Didiza as the mayoral candidate in the 2016 local government elections.

In sum then, the combination of weak participatory institutions, the limited reach of civil society outside of key formal domains, and party dominance over civil society in a socio-economic context in which the poor rely ever more heavily on the state for their well-being has created conditions conducive to various forms of mediatory politics. These are informal politics of representation and participation, outside of formal institutions (Piper \& von Lieres, 2015), in which poor and marginalized groups have to invent other means of being seen and heard by the state, and vary from insurgent citizenship, to quiet encroachment, to using party connections to secure services or welfare. Notably, the outcomes of informal forms of participation are diverse. Sometimes, they include benefits for marginalized groups that are arguably democratic. Many times, however, the outcomes of informal participation and mediatory politics can be coercive and clientelistic, or at the very least, a complex mix of democratic and non-democratic outcomes.

Often, some combination of these analytically distinct forms of mediation may coexist in practice. Thus, in a recent study of informal participation in a Cape Town township, Piper and Bénit-Gbaffou (2014) explore the challenges that confront leaders in representing the community as informal, unelected mediators. They show how community leaders mediate a complex set of contradictory 'popular, party, state, and personal demands', having to demonstrate efficacy in service delivery from local government without compromising multiple party affiliations. Piper and Bénit-Gbaffou (2014, p. 40) note that local leaders are likely to confront a range of different challenges that require 'doubledealing' that is:

... becoming an honest broker, by identifying and resolving the hard questions of the development vision largely determined at higher political levels; seeing off populist and disruptive rivals; managing the different 'sedation' pressures from competing parties; and resisting cooption by the state and the temptation to betray (contested and heterogeneous) community claims.

They argue that there is a high risk that the failure of the mediator translates into a failure of effective and legitimate representation for poor communities who have little access to formal institutions of representation. In sum then, Piper \& Bénit-Gbaffou's case illustrates the crucial role of effective yet informal mediation in overcoming the limits of institutionalized representation for the poor in the global South. It also speaks to the complexdemocratic and undemocratic-outcomes of informal forms of participation and representation.

\section{Conclusion: from formal participation to informal mediation}

The rise of an informal popular politics that includes a variety of forms of participation and mediated representation outside of the formal institutions of participatory governance and social movements in South Africa speaks to an ever-widening gap between state and society, and with it, an ever more precarious participatory project. In the scramble for livelihoods and security that increasingly depend on the state, and the use of informal as well 
as formal ways of accessing these resources, poor people tend to adopt diverse strategies and forms of participation. Some of these are clearly democratic, like forms of rightsbased citizenship that demand equal treatment under the law. Others, like clients who support political patrons in exchange for preferential access to state resources, are usually not. Some demand meaningful social change through insurgent forms of citizenship practice, while others even try to avoid the state, as they cannot live by its rules, quietly encroaching on the formal life of the city in sufficient numbers until they simply must be accommodated.

The growth of an informal politics of representation linked to these forms of politics sometimes creates new frontiers for participation. In particular, a new class of representative emerges-those who claim legitimacy and representativeness-but who are not formally authorized or legally recognized. Often, these political leaders speak for marginalized groups who would otherwise have no power; sometimes, they are sought out by the state to mediate with groups of citizens on its behalf. Notably, informal mediators are increasingly crucial for state-society relations not only in South Africa, but also more widely in the global South (Piper \& von Lieres, 2015). While some of these movements and mediators have secured democratic outcomes, others have demonstrated authoritarian practices and have secured only partial, short-term outcomes. Many of these local participatory spaces have had successes in mobilizing communities and in securing service delivery, but it remains to be seen if they can be effective in the longer term in forcing a wider and more deep-rooted state responsiveness to civil society.

In general, we conclude that the informal realm of popular politics and mediated representation speaks to the failure of institutionalized participatory governance and formal civil society-state relations to reduce the democratic deficit between state and society. More importantly, it speaks to the ways in which deeper structural conditions of marginalization and exclusion in highly unequal societies shape the limits and possibilities of participation and democratic representation. Above all, it focuses our attention on the need to democratize state power in society itself as a precondition for something like the participatory democracy imagined in the liberation discourse of the 1980s.

\section{Disclosure statement}

No potential conflict of interest was reported by the authors.

\section{References}

Africacheck. (2016). FACTSHEET: Social grants in South Africa - separating myth from reality. Africacheck: Sorting fact from fiction. Retrieved from https://africacheck.org/factsheets/ separating-myth-from-reality-a-guide-to-social-grants-in-south-africa/.

Alexander, P. (2010). Rebellion of the poor: South Africa's service delivery protests - a preliminary analysis. Review of African Political Economy, 37(123), 25-40.

Baiocchi, G., Heller, P., \& Silva, M. K. (2011). Bootstrapping democracy: Transforming local governance and civil society in Brazil. Stanford, CA: Stanford University Press.

Ballard, R., Habib, A., \& Valodia, I. (Eds.). (2006). Voices of protest: Social movements in post-apartheid South Africa. Pietermaritzburg: UKZN Press.

Barichievy, K., Piper, L., \& Parker, B. (2005). Assessing "Participatory governance" in local government: A case-study of two South African cities. Politeia, 24(3), 370-393. 
Bayat, A. (1997). The quiet encroachment of the ordinary. Chimmrenga, 8-15. Retrieved from http://chimurengachronic.co.za/quiet-encroachment-of-the-ordinary-2/

Bayat, A. (2000). From dangerous classes' to 'quiet rebels' politics of the urban subaltern in the global south. International Sociology, 15(3), 533-557.

Bénit-Gbaffou, C. (2008). Local councillors: Scapegoats for a dysfunctional participatory democratic system? Lessons from practices of local democracy in Johannesburg. Critical Dialogue: Public Participation in Review, 4(1), 26-33.

Bénit-Gbaffou, C. (2012, March). Party politics, civil society and local democracy - reflections from Johannesburg. Geoforum, 43(2), 178-189.

Bénit-Gbaffou, C. (Ed.). (2015) Popular politics in South African cities: Unpacking community participation. Pretoria: HSRC Press.

Booysen, S. (2011). The African National Congress and the regeneration of political power. Johannesburg: Wits University Press.

Buccus, I., Hemson, D., Hicks, J., \& Piper, L. (2008). Community development and engagement with local governance in South Africa. Community Development Journal, 43(3), 297-311.

Cornwall, A. (2002). Making spaces, changing places: Situating participation in development (IDS Working Paper No. 170). Brighton: Institute of Development Studies, University of Sussex.

Cornwall, A., \& Coelho, V. S. (Eds.). (2007). Spaces for change? The politics of participation in new democratic arenas. London: Zed.

Dagnino, E. (2003). Citizenship in Latin America: An introduction. Latin American Perspectives, 30 (2), 211-225.

Du Preez, M. (2016, May 24). Zuma 'a rent-seeker par excellence'. News24. Retrieved from http:// www.news24.com/Columnists/MaxduPreez/zuma-a-rent-seeker-par-excellence-20160524.

Friedman, S. (2006). Participatory governance and citizen action in post-apartheid South Africa (discussion paper no. 164). Geneva: Decent Work Programme, International Institute for Labour Studies.

Friedman, S., \& Mottiar, S. (2005). A rewarding engagement? The treatment action campaign and the politics of HIV/AIDS. Politics and Society, 33(4), 511-565.

Fung, A., \& Wright, E. O. (2001). Deepening democracy: Innovations in empowered participatory governance. Politics and Society, 29(1), 5-41.

Gaventa, J., McGee, R., \& Zipfel, T. (2007). How do local governments support citizen engagement? Background note for the International Workshop for Champions of Participation in Local Government. IDS workshop, University of Sussex, 29 May-4 June.

Greenstein, R. (2003). State, civil society and the reconfiguration of power in post-apartheid South Africa' (research report no. 8). Durban: Centre for Civil Society, University of KwaZulu-Natal.

Heller, P. (2001, March). Moving the state: The politics of democratic decentralisation in Kerala, South Africa, and Porto Alegre. Politics \& Society, 29(1), 131-163.

Heller P. (2009). Democratic deepening in Brazil, India and South Africa: Towards a comparative framework. Paper prepared for conference 'Building Sustainable Democracies', Indiana University, Bloomington (January 29-30). Retrieved from http://www.indiana.edu/ demsus/ docs/heller.pdf.

von Holdt, K. Langa, M. Malopo, S. Mogapi, N. Ngubeni, K. Dlamini, J., \& Kirsten, A. (2011). The smoke that calls: Insurgent citizenship and the struggle for a place in the new South Africa. Centre for the Study of Violence and Society, Work and Development Institute. Retrieved from http:// www.swopinstitute.org.za/node/286.

Holston, J. (2008). Insurgent citizenship: Disjunctions of democracy and modernity in Brazil. Princeton: Princeton University Press.

Jeeves, A. (2004). Assessing a decade of democracy in Southern Africa. Canadian Journal of African Studies, 38(3), 505-520.

von Lieres, B., \& Piper, L. (Eds.). (2014). Mediated citizenship: The informal politics of speaking for citizens in the global south. Basingstoke: Palgrave Macmillan.

von Lieres, B., \& Robins, S. (2008). Democracy and citizenship. In N. Shepherd \& S. Robins (Eds.), New South African keywords (pp. 47-57). Ohio, OH: Ohio University Press and Jacana Media. 
Meth, P. (2010). Unsettling insurgency: Reflections on women's insurgent practices in South Africa. Planning Theory and Practice, 11(2), 241-263.

Miraftab, F. (2006). Feminist praxis, citizenship and informal politics: Reflections on South Africa's anti-eviction campaign. International Feminist Journal of Politics, 8(2), 194-218.

Miraftab, F., \& Wills, S. (2005). Insurgency and spaces of active citizenship: The story of the western cape anti-eviction campaign in South Africa. Journal of Planning Education and Research, 25, 200-217.

Mohanty, R., Thompson, L., \& Coelho, V. S. (2011). Mobilising the state? Social mobilisation and state interaction in India, Brazil and South Africa(IDS working paper No. 359). Brighton: Institute of Development Studies, University of Sussex.

Ndletyana, M. (2015). African national Congress: From an emancipatory to a rent-seeking instrument. Transformation: Critical Perspectives on Southern Africa, 87, 95-116.

Piper, L. (2015). From party-state to party-society in South Africa: SANCO and the informal politics of community representation in Imizamo Yethu, Hout Bay, Cape Town. In C. Bénit-Gbaffou (Ed.), Popular politics in South African cities: Unpacking community participation (pp. 21-41). Pretoria: HSRC Press.

Piper, L., \& Anciano, F. (2015). Party over outsiders, centre over branch: How ANC dominance works at the community level in South Africa. Transformation: Critical Perspectives on Southern Africa, 87, 72-94.

Piper, L., Bafo, K., \& von Lieres, B. (2012). Opening policy space in the dominant party: The treatment action campaign, HIV/AIDS, and the reinvention of the ANC in South Africa. Unpublished research report.

Piper, L., \& Bénit-Gbaffou, C. (2014). Mediation and the contradictions of representing the urban poor in South Africa: The case of SANCO leaders in Imizamo Yethu in Cape Town, South Africa. In B. von Lieres \& L. Piper, (Eds.), Mediated citizenship: The informal politics of speaking for citizens in the global south (pp. 25-42). Basingstoke: Palgrave Macmillan.

Piper, L., \& Deacon, R. (2009). Too dependent to participate: Ward committees and local democratisation in South Africa. Local Government Studies, 35(4), 415-433.

Piper, L., \& von Lieres, B. (2008). Inviting failure: Public participation and local governance in South Africa. Participation and Governance, 1(1). Retrieved from http://fcis.oise.utoronto.ca/ daniel_sc/pipervonlieres.pdf

Piper, L., \& von Lieres, B. (2015). Mediating between state and citizens: The significance of the informal politics of third party representation in the global south. Citizenship Studies, 19(6-7), 696-713.

Piper, L., \& Nadvi, L. (2010). Popular mobilisation, party dominance and participatory governance in South Africa. In L. Thompson \& C. Tapscott (Eds.), Citizenship and social movements: Perspectives from the global south (pp. 212-238). London: Zed Books.

Pithouse, R. (2014). The shack settlement as a site of politics: Reflections from South Africa. Agrarian South: Journal of Political Economy, 3(2), 179-201.

Robins, S. (2014). Slow activism in fact times: Reflections on the politics of media spectacles after apartheid. Journal of Southern African Studies, 40(1), 91-110.

Robins, S., \& Fleisch, B. (2014). Mediating active citizenship and social mobility in working class schools: The case of equal education in Khayelitsha, Cape Town. In B. von Lieres \& L. Piper (Eds.), Mediated citizenship: The informal politics of speaking for citizens in the global south (pp. 128-145). Basingstoke: Palgrave Macmillan.

Robins, S., \& von Lieres, B. (2008). Remaking citizenship, unmaking marginalization: The treatment action campaign in post-apartheid South Africa. In A. H. Jeeves \& G. Cuthbertson (Eds.), Fragile freedom: Democracy's first decade in South Africa (pp. 127-145). Tshwane: University of South Africa Press.

Zuern, E. (2011). The politics of necessity: Community organising and democracy in South Africa. Pietermaritzburg: University of KwaZulu-Natal Press. 